\title{
Serum epidemiological survey and risk factors investigation for lentivirus in goats from Sisal Region, Bahia, Brazil
}

\author{
Inquérito soroepidemiológico e fatores de risco para \\ lentivírus em rebanhos caprinos da região sisaleira, Bahia
}

\author{
Danielle Nobre Santos Pinheiro ${ }^{*}$, Joselito Nunes Costa², Thiago Sampaio de Souza', \\ Vanderlan Warlington Souza Santos ${ }^{3}$, Dalva Alana Azevedo ${ }^{4}$, \\ Antônio Oliveira Costa Neto ${ }^{5}$, Raymundo Rizaldo Pinheiro ${ }^{6}$
}

\begin{abstract}
This study aimed to carry out a serum epidemiological survey of goat arthritis encephalitis in the sisal region of Bahia, Brazil, and to evaluate risk factors. We evaluated 831 samples of goat blood serum among males and females older than six months, from 49 farms distributed among the municipalities of Araci, Cansanção, Conceição do Coité, Itiúba, Monte Santo, Nordestina, Queimadas, Santa Luz, São Domingos and Valente. An epidemiological questionnaire for the analysis of possible risk factors was applied. All sera were tested for immune-agar gel. The seroprevalence obtained in surveyed herds was $1.56 \%(13 / 831)$. There was significant difference $(\mathrm{p}<0.05)$ for animal racial pattern, type of farming and breeding systems. However, when considering herds with predominantly dairy breeds (Saanen and Alpine Pardo), the seropositivity in animals from Valente, Conceição do Coité and São Domingos amounted to 5.06\% (12/237). In these municipalities, from 14 properties analyzed, five $(38.5 \%)$ had at least one positive-testing animal. This result is extremely worrying when one considers that few control measures are adopted by farmers to prevent the goat arthritis encephalitis in the most important dairy region of Bahia state.
\end{abstract}

KEYWORDS: serology; cae; lentivirus small ruminants; sisal territory; goats.
RESUMO: Este trabalho teve por objetivo realizar um levantamento soroepidemiológico da artrite encefalite caprino na região sisaleira do estado da Bahia e avaliar os fatores de risco. Foram avaliadas 831 amostras de soros sanguíneos de caprinos entre machos e fêmeas, com idade superior a seis meses, provenientes de 49 propriedades rurais distribuídas entre os municípios de Araci, Cansanção, Conceição do Coité, Itiúba, Monte Santo, Nordestina, Queimadas, Santa Luz, São Domingos e Valente. Foi aplicado um questionário epidemiológico destinado à análise de possíveis fatores de risco. Todos os soros foram submetidos ao teste da imunodifusão em gel de ágar. A soroprevalência obtida nos rebanhos pesquisados foi de $1,56 \%$ (13/831). Houve diferença significativa $(p \leq 0,05)$ para padrão racial dos animais, tipo de exploração e sistemas de criaçáo. Quando se consideraram apenas os rebanhos com raças predominantemente leiteiras (Saanen e Pardo alpina), dos municípios de Valente, Conceição do Coité e São Domingos, a soropositividade nos animais elevou-se para 5,06\% (12/237). Nesses municípios, de 14 propriedades analisadas, $5(38,5 \%)$ apresentaram pelo menos um animal sororeagente. Esse resultado é extremamente preocupante quando se constata que poucas medidas de controle são adotadas pelos criadores para impedir a disseminação dessa importante enfermidade na bacia leiteira mais relevante do estado da Bahia.

PALAVRAS-CHAVE: sorologia; artrite encefalite caprino; lentivírus de pequenos ruminantes; território do sisal; caprinos.

\footnotetext{
'Hospital Veterinário, Universidade Federal do Recôncavo da Bahia, Agricultural, Environmental and Biological Sciences Center Cruz das Almas (BA), Brazil

¿Universidade Federal do Recôncavo da Bahia, Agricultural, Environmental and Biological Sciences Center - Cruz das Almas (BA), Brazil ${ }^{3}$ Postgraduate Program in Animal Science, Universidade Federal Rural do Semiárido - Mossoró (RN), Brazil

${ }^{4}$ Graduate Program in Veterinary Sciences, Universidade Estadual do Ceará, Fortaleza (CE), Brazil

${ }^{5}$ Department of Biology, Universidade Estadual de Feira de Santana - Feira de Santana (BA), Brazil

${ }^{6}$ Brazilian Agricultural Research Corporation, Embrapa Goats and Shee - Sobral (CE), Brazil

*Corresponding author: danyvet10@gmail.com

Received on: $11 / 25 / 2016$. Accepted on: 04/05/2018
}

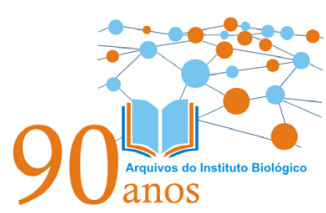




\section{INTRODUCTION}

Over the last decades, the goat breeding has gotten prominence in national scenario. In 2013, the goat herd reached approximately 8.779 million of heads, of which 2.458 million are in the state of Bahia (IBGE, 2013). Several factors interfere in goat breeding yield development (GONÇALVES et al., 2008). Several diseases cause high losses in the sheep and goat breeding. Among them, we can highlight those ones of viral origin. In this context, caprine arthritis encephalitis (CAE), which is a chronic-progressive course disease, caused by a non-oncogenic retrovirus belonging to the lentivirus group of small ruminants (LVPR), is disseminated in the body without any clinical sign for months or years (STRAUB, 2004). Sick animals may develop clinical conditions characteristic of arthritis, mastitis, encephalitis, pneumonia, and progressive weigh loss (CALLADO et al., 2001; FRANKE, 1998).

The main transmission rout of the agent is through the ingestion of contaminated colostrum and milk (PINHEIRO et al., 2003). Direct contact between animals, as well as indirect contact with body fluids of infected animals, is other important form of virus transmission (SOUZA et al. 2014). Serological methods are widely used to aid lentivirus infection diagnosis. The agar gel immunodiffusion (AGID) test is the one chosen by the World Organization for Animal Health (OIE) to diagnose goats lentivirus (LVC), because it is highly specific, practical and simple to perform (OIE, 2008).

Bahia is the Brazilian state with the highest concentration of goats, and, among Bahia municipalities, those belonging to sisal territory stand out in goat breeding. Nevertheless, there is no serum epidemiological survey in this region, which, besides standing out in dairy production, has a goat breeding program, with the acquisition of matrices and breeders from other regions, which can also lead to the dissemination of LVC, unless control measures are taken. Therefore, considering the socioeconomic importance of goat breeding in the sisal region, and the socioeconomic impact that LVC can provide in farming activity, this work was elaborated aiming to carry out epidemiological serum study of caprine arthritis encephalitis in caprine herds in sisal territory, Bahia, evaluating risk factors.

\section{MATERIAL AND METHODS}

\section{Location}

The epidemiological evaluation was carried out in sisal territory, constituted by 20 municipalities, with the territorial extension of $20,154 \mathrm{~km}^{2}$, corresponding to $3.5 \%$ of Bahia state (ANDRADE et al., 2013). Goat population in municipalities belonging to the sisal region is of 197,242 heads, corresponding to $8.12 \%$ of Bahia herd (IBGE, 2012). Samples were collected from Araci, Cansanção, Conceição do Coité, Itiúba, Monte Santo, Nordestina, Queimadas, Santa Luz, São Domingos and Valente, from the sisal region, which presents a higher herd of goats destined for milk and meat of the researched region (Fig. 1).

\section{Registration of the properties and clinical evaluation of surveyed animals}

The properties visited were registered and the animals that participated in the research were identified with collar/earring. In addition, a questionnaire containing property data, herd data, sanitary management, reproductive management and calves management was applied in order to characterize the breeding system of the studied region and to correlate the risk factors for the occurrence of arthritis encephalitis in goats. The animals were clinically evaluated, seeking changes characteristic of CAE, according to CALLADO et al. (2001). In the study, a racial type was not established as a harvest criterion, being a factor dependent on each property visited.

\section{Sample Collection}

Blood samples were collected, after adequate antisepsis, by jugular venipuncture, using vacuum tubes. With clot formation, the tubes were centrifuged at $1,500 \mathrm{~g}$ for 10 minutes to

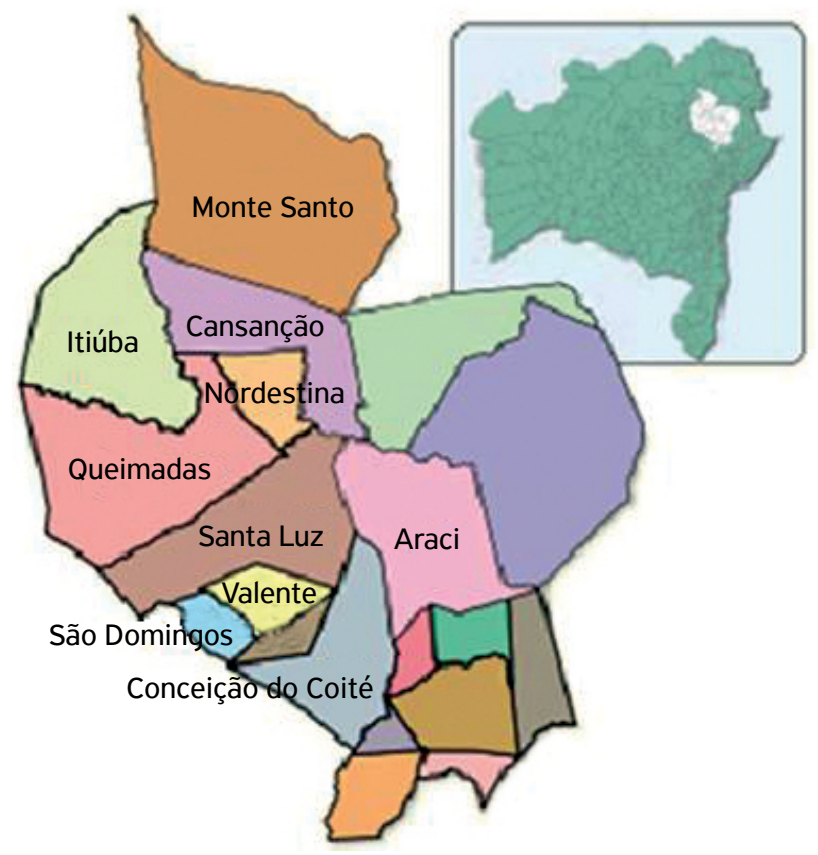

Source: MDA, 2011 (Modified).

Figure 1. Map of the sisal territory of Bahia state, Brazil, highlighting the municipalities selected for the research. 
obtain the sera, which were packed in microtubes, identified and stored at $-20^{\circ} \mathrm{C}$ until the serological test.

\section{Serological Testing}

In LVC antibodies detection, the AGID technique was performed at the National Research Center of the Brazilian Agricultural Research Corporation (Empresa Brasileira de Pesquisa Agropecuária - Embrapa Caprinos e Ovinos) using a national antigen produced at Embrapa Virology Laboratory, from cell supernatants caprine synovial membrane (MSC) infected with the CAE virus (CAEV-Cork strain). The antigen used in the AGID test was obtained by ultrafiltration of viral supernatant in the AMICON system (Millipore Bedford, MA) with $10 \mathrm{KDa}$ membrane treated with ethyl ether (PINHEIRO et al., 2010).

\section{Statistical analysis}

The minimum number of samples was calculated according to THRUSFIELD (2004), with the confidence level of $99 \%$ and sampling error of $5 \%$, as the expected prevalence of $50 \%$, resulting in 663 minimum samples. The minimum sample of 15 animals per property, between males and females, aged over six months, was suggested by MARTINEZ et al. (2010). Thus, the total of samples collected, from April 2013 to September 2014, was of 831 samples, from 49 properties. Participating properties were selected by non-probabilistic method. For CAE risk factor evaluation, a univariate analysis was performed for by the point and interval estimates of the odds ratio (OR) (THRUSFIELD, 2004). The statistical analysis was performed using the PAST 2.02 statistical software (ARANGO, 2005; HAMMER et al., 2012).

This study followed the norms established by the Ethics Committee on the Use of Animals of Veterinary Medicine and Animal Science College at Universidade Federal da Bahia (CEUA / MEVZ-UFBA), according to the protocol no. $13 / 2012$.

\section{RESULTS AND DISCUSSION}

The serological evaluation found out that, from the 831 tested animals in sisal territory by the AGID test, $1.56 \%(13 / 831)$ were seroreagent. Among the ten cities surveyed, $30 \%(3 / 10)$ had reactive animals (Table 1 ).

The prevalence obtained in this study was higher than that observed by SARDI et al. (2005), which evaluated goats farmed on properties in the Portal do Sertão, Jacuípe Basin and sisal territory, also in the state of Bahia, where they detected $0.6 \%$ (5/755) of LVC seropositivity.
Of the 49 properties participating on the research, $12.24 \%(6 / 49)$ presented seropositive animals for LVC. Among surveyed ten municipalities, Valente presented $12.50 \%(1 / 8)$ of positivity in the properties surveyed, and in Santo Domingo 80\% (4/5) of the properties presented at least one positive animal (Table 2). This probably was due to the fact that these municipalities concentrate the greatest number of properties exclusively dedicated to milk

Table 1. Serological prevalence of caprine arthritis encephalitis in the sisal territory, Bahia, Brazil, by the agar gel immunodiffusion (AGID) test.

\begin{tabular}{lccc} 
Municipalities & $\begin{array}{c}\text { Number of } \\
\text { collected } \\
\text { samples/ } \\
\text { municipality }\end{array}$ & $\begin{array}{c}\text { Number of } \\
\text { positive } \\
\text { samples }\end{array}$ & $\begin{array}{c}\text { Prevalence } \\
\text { (\%) }\end{array}$ \\
\hline Araci & 31 & 0 & 0 \\
\hline Cansanção & 103 & 0 & 0 \\
\hline $\begin{array}{l}\text { Conceição } \\
\text { do Coité }\end{array}$ & 20 & 1 & 5.00 \\
\hline Itiúba & 75 & 0 & 0 \\
\hline Monte Santo & 274 & 0 & 0 \\
\hline Nordestina & 35 & 0 & 0 \\
\hline Queimadas & 45 & 0 & 0 \\
\hline São Domingos & 94 & 9 & 9.57 \\
\hline Santa Luz & 31 & 0 & 0 \\
\hline Valente & 123 & 3 & 2.44 \\
\hline Total & 831 & 13 & 1.56 \\
\hline
\end{tabular}

Table 2. Number of positive properties in the serological survey of goat arthritis encephalitis, in sisal territory, Bahia, Brazil, via agar gel immunodiffusion (AGID) technique.

\begin{tabular}{lccc} 
Municipality & $\begin{array}{c}\text { Number of } \\
\text { properties }\end{array}$ & $\begin{array}{c}\text { Number of } \\
\text { positive } \\
\text { properties }\end{array}$ & $\begin{array}{c}\text { Prevalence } \\
(\%)\end{array}$ \\
\hline Araci & 2 & 0 & 0 \\
\hline Cansanção & 6 & 0 & 0 \\
\hline Conceição do & 1 & 1 & 100.00 \\
Coité & 5 & 0 & 0 \\
\hline Itiúba & 15 & 0 & 0 \\
\hline Monte Santo & 2 & 0 & 0 \\
\hline Nordestina & 3 & 0 & 0 \\
\hline Queimadas & 5 & 4 & 80.00 \\
\hline São Domingos & 2 & 0 & 0 \\
\hline Santa Luz & 8 & 1 & 12.50 \\
\hline Valente & 49 & 6 & 12.24 \\
\hline Total & & & \\
\hline
\end{tabular}


production, with common practices of trading animals with other municipalities and often without negative CAE test. The practice of introducing animals into the herd, on properties with an inefficient sanitary control, can facilitate the introduction and dissemination of goat lentivirus in the herd (PINHEIRO et al., 2001).

Regarding the number of seropositive properties, similar results were found by LIMA et al. (2013), who identified seropositivity in $15.22 \%$ (7/46) of the properties analyzed in a serological survey for the CAE in the region of Juazeiro, Bahia.

With respect to the breed pattern of surveyed herds in sisal region, there was predominance of without defined racial pattern (PRDW) animals: 618 (74.36\%), followed by Parda Alpina, 114 (13.71\%); and Saanen, 99 (11.91\%). Correlating the LVC serological results among dairy goats (Parda Alpina and Saanen) and PRDW, we found that dairy farmers presented prevalence of $92.31 \%(12 / 213)$ and PRDW goats of $7.69 \%$ (1/618) (Table 3). Significant difference was observed on positivity rates when comparing the dairy breeds with PRDW animals. Significant association between breed and seroprevalence for LVC had also been noted by MOURA SOBRINHO (2008) and PINHEIRO et al. (2004). The existence of LVC in dairy herds creates the possibility of dissemination and

Table 3. Statistical analysis of the serological results for goat lentivirus on dairy breeds (Parda Alpina and Saanen) and without defined racial pattern (SPRD), from the sisal territory, Bahia, Brazil.

\begin{tabular}{lccc} 
Breed & $\begin{array}{c}\text { Positive } \\
\text { animals }\end{array}$ & $\begin{array}{c}\text { Negative } \\
\text { animals }\end{array}$ & Total \\
\hline $\begin{array}{l}\text { Dairy breed } \\
\text { (Parda Alpina } \\
\text { and Saanem) }\end{array}$ & $12(92.31)$ & $201(24.57)$ & $213(25.63)$ \\
\hline SPRD & $1(7.69)$ & $617(75.43)$ & $618(74.37)$ \\
\hline Total & $13(100)$ & $818(100)$ & $831(100)$ \\
\hline
\end{tabular}

$\chi^{2}=30.801 ; p<0.05$. infection of the PRDW herds and locally adapted breeds (PINHEIRO et al., 2004).

Considering the herds with predominantly dairy breeds (Saanen and Pardo Alpina), from Valente and São Domingos, the seropositivity in the animals increased 5.06\% (12/237). In these municipalities, from 13 analyzed properties, five (38.5\%) presented at least one seroreagent animal.

In reference to the risk factors associated to the occurrence of CAE in herds of selected goats in the sisal region, relevant characteristics such as breeding system, types of exploitation, breeders' acquisition, weaning age, type of reproduction, herd origin, participation on exhibitions and documentation requirements were pointed out. However, a significant difference was observed only for the breeding system and the type of production (Table 4).

Concerning the breeding system, it was observed that the positive animals were mostly from herds raised in a semi-intensive system, $31.57 \%$ (5/19), followed by extensive breeding, $3.33 \%(1 / 30)$. Thus, it can be stated that the semi-intensive breeding regime was statistically significant for the occurrence of seropositivity $(\mathrm{p} \leq 0.05)$.

In respect of the breeding system, the results of the present study corroborate the assessment carried out by MOURA SOBRINHO (2008), which describes the highest occurrence of seropositivity for LVC in semi-intensive rearing systems, $28.4 \%(4 / 14)$, in comparison to those raised in the extensive rearing system, $6.6 \%(1 / 15)$. In extensive rearing, the intimate and constant contact between the individuals on herd occurs less frequently. However, the intensive or semi-intensive breeding system provides a greater body contact between the animals, facilitating the virus spreading in the herd (MELO; FRANKE, 1997). However, although the herds raised in intensive and semi-intensive systems are more susceptible to viral infection, animals submitted to the extensive system can be infected by LVC (SOUZA et al., 2007).

In the matter of the type of production evaluated in the herds surveyed, it was found that animals destined to milk

Table 4. Evaluation of the risk factors with the respective odds ratio (OR) and random occurrence probability (p).

\begin{tabular}{lcccc} 
Factors & & OR & \multicolumn{1}{c}{ IC95\% } & p-value \\
\hline Rearing system & Extensive/semi-extensive & 0.07 & $0.01-0.69$ & $0.02 *$ \\
\hline Type of breeding & Goats/goats and sheep & 4.06 & $0.70-23.47$ & 0.22 \\
\hline Breeders & Bought/raised on property & 0.40 & $0.01-0.57$ & 0.97 \\
\hline Weaning age & 5 to 60 days/60 to 120 days & 6.67 & $0.046-96.45$ & 0.61 \\
\hline Type of production & Milk/meat & 17.33 & $1.83-164.23$ & $0.01 *$ \\
\hline Herd origin & Local (other municipality)/ other state & 11.00 & $1.12-108.49$ & 0.11 \\
\hline Participate on exhibitions & Yes/no & 0.09 & $0.01-0.90$ & 0.11 \\
\hline Required documentation & Yes/no & 3.33 & $0.26-42,66$ & 0.90 \\
\hline
\end{tabular}

IC: confidence interval of $5 \% ; p<0.05)$. 
production are statistically more likely to become infected $(\mathrm{p} \leq 0.05)$ than animals reared for meat (Table 4). It can be deduced that dairy animals, for being generally reared in a semi-intensive or intensive breeding system and remaining longer in the production system, become more susceptible to viral infection.

Regarding the types of breeding, it was verified that there is no significant association ( $\mathrm{p} \geq 0.05$ ) between the combined breeding of sheep and goats and exclusive breeding. The interspecies transmission of LVPR has already been reported and described in experimental, epidemiological and phylogenetic studies by several authors (SOUZA et al., 2014; GJERSET et al., 2009; SHAH et al., 2004a; 2004b; PASICK, 1998; ZANON, 1998). Recently, studies have demonstrated the transmission of LVPR in ovine neonates through ingestion of colostrum and milk contaminated with goat lentivirus and prolonged direct contact between adult goats and sheep (SOUZA et al., 2015).

\section{CONCLUSIONS}

In view of the reported here, it was found out that lentivirus is present in the goat herd of the sisal region, even in a discrete way. However, the detection of the highest positivity indexes in the municipalities where the highest milk production is concentrated represents a concern, since an effective policy to control the disease in the region has not yet been observed. Thus, it is necessary to implement the control and prophylaxis program recommended by the National Caprine and Ovine Health Plan (Programa Nacional de Sanidade dos Caprinos e Ovinos - PNSCO) in order to promote the control of goat lentivirus in the sisal region.

\section{ACKNOWLEDGMENTS}

To the goat farmers from sisal territory, for entrusting the work and participating in it; to the Association for the Sustainable Development and Solidarity of the Sisaleira Region (Associação de Desenvolvimento Sustentável e Solidário da Região Sisaleira - APAEB) and Rural Unions of the Sisal Region, for cooperating and supporting the accomplishments of the collections; to the Viruses Laboratory at the Brazilian Agricultural Research Company - Goat and Sheep (EMBRAPA - Caprina and Ovina), for the laboratory structure used to perform the exams.

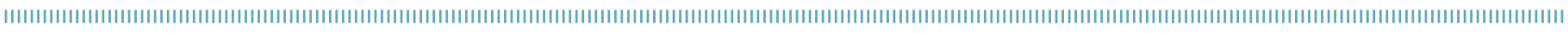
REFERENCES

AYRES, M.; AYRES Jr, M.; AYRES, D.L.; SANTOS, A.S. Bioestat 5.O: Aplicações estatísticas na área de ciências biológicas e médicas. Belém: Sociedade Civil Mamirauá.

ANDRADE, R.; FERREIRA, I. Cabra leiteira: Fonte de Renda para o Sertanejo; a Experiência do Território do Sisal. Bahia Agrícola, v.9, n.2, p.12-15, 2013.

ARANGO, H.G. Bioestatística: teórica e computacional. 2ed. Rio de Janeiro: Editora Guanabara Koogan, 2005. 423p.

BRASIL, IBGE. Instituto Brasileiro de Geografia e Estatística. Produção Pecuária Municipal 2013. Available from: <http://ftp:// ftp.ibge.gov.br/Producao_Pecuaria/Producao_da_Pecuaria_ Municipal/2013/ppm2013.pdf>. Accessed on: 22 Mar. 2014.

BRASIL, IBGE. Instituto Brasileiro de Geografia e Estatística. Produção Pecuária Municipal 2012. Available from: <ftp:// ftp.ibge.gov.br/Producao_Pecuaria/Producao_da_Pecuaria_ Municipal/2012/ppm2012.pdf>. Accessed on: 10 Aug. 2013.

CALLADO, A.K.C.; CASTRO, R.S.; TEIXEIRA, S.M.F. Lentivírus de pequenos ruminantes (CAEV e Maedi-visna): Revisão e Perspectivas. Pesquisa Veterinária Brasileira, Rio de Janeiro, v.21, n.3, p.87-97, 2001.

FRANKE, C.R. Uma virose emergente ameaça o rebanho caprino nacional: Artrite Encefalite Caprina (CAE). Secretaria de Agricultura,
Irrigação e Reforma Agrária. Revista Bahia Agrícola, v.2, n.3, p.89-92, 1998.

GJERSET, B.; RIMSTAD, E.; TEIGE, J.; SETAERT, K.; JONASSEN, M.C. Impact of natural sheep-goat transmission on detection and control of small ruminant lentivirus group $\mathrm{C}$ infections. Veterinary Microbiology, v.135, p.231-238, 2009.

GONÇALVES, A.L.; LANA, R.P.; VIEIRA, R.A.M.; HENRIQUE, D.S.; MANCIO, A.B.; PEREIRA, J.C. Avaliação de sistemas de produção de caprinos leiteiros na Região Sudeste do Brasil. Revista Brasileira de Zootecnia, v.37, n.2, p.366-376, 2008.

HAMMER, Ø.; HARPER, D.A.T.; RYAN, P.D. Paleontological statistics software package for education and data analysis. 2001. Available from: <http://folk.uio.no/ohammer/past/> Accessed on: 08 Dec. 2014.

LIMA, C.C.V.; COSTA, J.N.; SOUZA, T.S.; MARTINEZ, P.M.; COSTA NETO, A.O.; AZEVEDO, D.A.A.; PINHEIRO, R.R.;BRITO, R.L.L.; Imunodiagnóstico para a artrite encefalite caprina em rebanhos do semiárido Baiano, Brasil. Revista Brasileira de Medicina Veterinária, v.35, n.4, p.358-364, 2013.

MARTINEZ, P.M.; COSTA, J.N.; SOUZA, T.S.; COSTA NETO, A.O.; PINHEIRO, R.R. Sistemas de criação de ovinos e ocorrência de anticorpos contra o vírus da Maedi-Visna na Microrregião de Juazeiro - Bahia. Revista Brasileira de Saúde e Produção Animal, v.11, n.2, p.342-353, 2010. 
MELO, A.C.M.; FRANKE, C.R. Soroprevalência da infecção pelo vírus da artrite - encefalite caprina (CAEV) no rebanho de caprinos leiteiros da região da grande Fortaleza, Ceará. Ciência Rural, v.27, n.1, p.13-117, 1997.

MOURA SOBRINHO, P.A.M.; FERNANDES, C.H.C.; RAMOS, T.R.R.; CAMPOS, A.C.; COSTA, L.M.; CASTRO, R.S. Prevalência e fatores associados à infecção por lentivírus de pequenos ruminantes em ovinos no estado do Tocantins. Ciência Veterinária nos Trópicos, v. 11, p.66-72, 2008.

Organização Mundial da Saúde Animal. Oie manual of diagnostic tests and vaccines for terrestrial animals. caprine arthritis encephalitis \& Maedi-Visna, 2008. Available from: <http://www.oie. int/fileadmin/Home/eng/Health_standards/tahm/2.07.03-04_ CAE_MV.pdf> Accessed on: 10 June 2013.

PASICK, J. Maedi-Visna virus and caprine arthritis-encephalitis virus: distinct species or quasispecies and its implications for laboratory diagnosis. Canadian Journal of Veterinary Research, v.62, p. 241-244, 1998.

PINHEIRO, R.R.; GOUVEIA, A.M.G.; ALVES, F.S.F. Prevalência da infecção pelo vírus da artrite encefalite caprina no estado do Ceará, Brasil. Ciência Rural, v.31, n.3, p.449-454, 2001.

PINHEIRO, R.R.; CHAGAS, A.C.S.; ANDRIOLI, A.; ALVES, F.S.F. Viroses de pequenos ruminantes. Sobral: Embrapa Caprinos e Ovinos, 2003. 30p. (Documento 46).

PINHEIRO, R.R.; GOUVEIA, A.M.G.; ALVES, F.S.F.; ANDRIOLI, A. Perfil de propriedades no estado do Ceará relacionado à presença do lentivírus caprino. Ciência Animal, v.14, n.1, p.29-372, 2004.

PINHEIRO, R.R.; ANDRIOLI, A.; GOUVEIA, A.M.G.; ARAGÃO, M.A.C.; MARTINEZ, P.M. Avaliação de antígenos para o diagnóstico de lentivírus em 332 rebanho caprino sob programa de controle. Arquivo Instituto Biológico, v.77, n.1, p.133-137, 2010.

SARDI, S.I.; SENA, G.S.R.; CAMPOS, G.S.; SANTOS, G.S.; MAIA NETO, A.L.; AVILA, L.N. Ocorrência de lentivírus de pequenos ruminantes no semiárido baiano e perfil da caprino/ovinocultura na região. Ciência Animal Brasileira, v.13, n.4, p.1-4, 2012.
SHAH, C.A.; BÖNI, J.; HUDER, J.B.; VOGT, H.R.; MÜHLLHER, J.; ZANONI, R.; MISEREZ, R.; LUTZ, H.; SCHÜPBACH, J. Phylogenetic analysis and reclassification of caprine and ovine lentiviruses based on 104 new isolates: evidence for regular sheep-to-goat transmission and world-wide propagation throught livestock trade. Virology, v.319, p.12-26, 2004a.

SHAH, C.; HUDER, J.B.; BÖNI, J.; SCHÖNMANN, M.; MÜHLHERR, J.; LUTZ, H.; SCHÜPBACH, J. Direct Evidence for Natural Transmission of Small-Ruminant Lentiviruses of Subtype A4 from Goat to Sheep and vice - versa. American Society for Microbiology, v.78, n. 14, p.7518-7522, 2004b.

STRAUB, O.C. Maedi-Visna virus infection in sheep. History and present knowledge. Comparative Immunology Microbiology $\odot$ Infectious Diseases, v.27, p.1-5, 2004.

SOUZA, T.S.; COSTA, J.N.; MARTINEZ, P.M.; PINHEIRO, R.R. Estudo sorológico da Maedi-Visna pelo método da imunodifusão em gel de ágar em rebanhos ovinos de Juazeiro, Bahia. Revista Brasileira de Saúde e Produção Animal, v.8, n.4, p.276-282, 2007.

SOUZA, T.S.; COSTA, J.N.; PINHEIRO, R.R.; LIMA, C.C.V.; MELO, F.C.C.; ANDRIOLI, A.; AZEVEDO, D.A.A.; SANTOS, V.W.S.; OLIVEIRA, E.L.O.; COSTA NETO, A.O. Duração da imunidade passiva para lentivírus de pequenos ruminantes em cordeiros. Semina: Ciências Agrárias, v.35, n.2, p.845-856, 2014.

SOUZA,T.S.; PINHEIRO,R.R.; COSTA,J.N.; LIMA,C.C.V.; ANDRIOLI,A.; AZEVEDO,A.A.;SANTOS,V.W.S.;ARAÚJO,J.F.; SOUZA,A.L.M.; PINHEIRO,D.N.S.;FERNANDES,F.M.C.; NETO,A.O.C. Interspecific transmission of small ruminant lentiviruses from goats to sheep. Brazilian Journal of Microbiology. vol.46, n.3, p.867-874, 2015.

STRAUB, O.C. Maedi-Visna virus infection in sheep.History and present knowledge. Comparative Immunology Microbiology $\diamond$ Infectious Diseases, v.27, p.1-5, 2004.

THRUSFIELD, M. Epidemiologia Veterinária. 2. ed. São Paulo: Roca. 2004. 556p.

ZANONI, R.G. Phylogenetic analysis of small ruminant lentiviruses. Journal of General Virology, v.79, p.1951-1961, 1998. 